\title{
Formation of Aliphatic and Aromatic $\alpha$-Hydroxy Ketones by Zygosaccharomyces bisporus
}

\author{
Frauke Neuser, Holger Zorn and Ralf G. Berger* \\ Institut für Lebensmittelchemie, Universität Hannover, Wunstorfer Straße 14, \\ D-30453 Hannover, Germany. Fax: 0049-511-7624547. \\ E-mail: rg.berger@mbox.lci.uni-hannover.de \\ * Author for correspondence and reprint requests \\ Z. Naturforsch. 55c, 560-568 (2000); received February 22/March 10, 2000 \\ Zygosaccharomyces bisporus, Acyloin Formation, Pyruvate Decarboxylase
}

The wild-type yeast strain Zygosaccharomyces bisporus CBS 702 produced $\alpha$-hydroxyketones (acyloins) from amino acid precursors after transamination to the corresponding 2-oxo acids. The key enzyme of the subsequent decarboxylation and $\mathrm{C}-\mathrm{C}$ bond forming reaction, pyruvate decarboxylase (PDC), was examined for its substrate- and stereo-specificity. A wide variety of saturated and unsaturated aliphatic and aromatic aldehydes was successfully converted to acyloins. 19 of the biotransformation products identified had not been reported as natural substances before. Product yields were strongly affected by substrate structure.

\section{Introduction}

Pyruvate decarboxylase (PDC, E. C. 4.1.1.1) is a key enzyme in alcoholic fermentation and catalyses the non-oxidative decarboxylation of pyruvate and other 2-oxo acids to the corresponding aldehydes. Thiamine diphosphate (ThDP) and $\mathrm{Mg}^{2+}$ ions are required as cofactors, which are bound to the apoenzyme in a quasi-irreversible manner at pH-values below 7.0 (Gounaris et al., 1975). PDC was first detected in yeast extracts by Neuberg and Karczag (1911) and has been found in many other fungi, plants, and bacteria (Bringer-Meyer et al., 1986; Rivoal et al., 1990). The catalytically active form is tetrameric (dimer of dimers) with a molecular mass of about $240 \mathrm{kDa}$ in most species, but higher active association states have been described for PDC from pea (Mücke et al., 1995) and wheat germ (Zehender et al., 1987).

The formation of acyloins (carboligation) as a side reaction of pyruvate decarboxylase has been assumed since Dirscherl's work (1931). In fact, Neuberg and Hirsch (1921) were the first to observe the production of $R$-1-hydroxy-1-phenylpropan-2-one (PAC, phenylacetyl carbinol) from benzaldehyde by fermenting yeast, but considered a new enzyme called "carboligase" to exist apart from PDC. The synthesis of $R$-PAC as a chiral precursor for L-ephedrine in the 1930ies was one of the first industrially applied biotransformations and is a matter of continuing research (Pohl, 1997). Unequivocal proofs for PDC as key enzyme of this biotransformation were obtained by several studies using partially purified PDC from different organisms to generate acyloins (Chen and Jordan, 1984; Bringer-Meyer and Sahm, 1988; Crout et al., 1991).

The carboligase reaction of PDC from yeast has been intensively studied with acetaldehyde as donor, which may be condensed to a wide range of aromatic and heterocyclic aldehydes, while aliphatic aldehydes usually are reported to fail as acetyl acceptors (Fuganti and Grasselli, 1985; Long et al., 1989; Cardillo et al., 1991; Crout et al., 1991; Bornemann et al., 1996). Most of these studies have been performed with fermenting yeast cells as in the case of the only detailed investigation reporting the successful conversion of aliphatic aldehydes (Schmauder and Gröger, 1968). During our work with different wild type yeast species, a strain of Zygosaccharomyces bisporus was found to transform amino acids into aromatic (Neuser et al., 1999) and aliphatic acyloins that had not been described in literature before. After the setup of a fast purification method for PDC from Z. bisporus, the objective of our studies was to examine the suitability of aliphatic aldehydes and 2-oxo acids to serve as substrates in the PDC catalysed formation of $\alpha$-hydroxyketones. 


\section{Materials and Methods}

\section{Biotransformations with fermenting yeast}

Zygosaccharomyces bisporus CBS 702 was obtained from the Centraalbureau voor Schimmelcultures (Baarn, Netherlands). After 48 h of precultivation at $24{ }^{\circ} \mathrm{C}$ in a standard medium $\left(30 \mathrm{~g} \mathrm{l}^{-1}\right.$ glucose, $3 \mathrm{~g} \mathrm{l}^{-1}$ yeast extract, $4.5 \mathrm{~g} \mathrm{l}^{-1}$ asparagine, $1 \mathrm{~g} \mathrm{l}^{-1} \mathrm{MgSO}_{4}, 1.5 \mathrm{~g} \mathrm{l}^{-1} \mathrm{KH}_{2} \mathrm{PO}_{4}, \mathrm{pH} 6.0$ ), yeast cells were transferred to shake flasks containing $100 \mathrm{ml}$ transformation medium $\left(10 \mathrm{~g} \mathrm{l}^{-1}\right.$ glucose, $8 \%$ (v/v) ethanol, $1 \mathrm{~g} 1^{-1} \mathrm{MgSO}_{4}, \quad 0.5 \mathrm{~g} \mathrm{l}^{-1}$ $\mathrm{KH}_{2} \mathrm{PO}_{4}, 2 \mathrm{mg} \mathrm{l}^{-1}$ thiamine, $2 \mathrm{mg} \mathrm{l}^{-1}$ biotin, $\mathrm{pH}$ 6.0). The respective amino acid precursor was the only source of nitrogen $(10 \mathrm{~mm})$. If aldehydes or oxo acids were to be converted $(10 \mathrm{~mm}$, added in two portions on growth days 2 and 5), $1 \mathrm{~g} \mathrm{l}^{-1}$ $\left(\mathrm{NH}_{4}\right)_{2} \mathrm{SO}_{4}$ was provided as nitrogen source. After $7 \mathrm{~d}$ of cultivation, cells were separated by centrifugation $(5000 \times g)$ and the broth was extracted with ethyl acetate $(3 \times 40 \mathrm{ml})$. The extract was dried over anhydrous sodium sulfate and concentrated using a Vigreux column.

\section{Enzyme purification}

For the isolation of pyruvate decarboxylase, yeast cells were transferred after precultivation to a growth medium containing $50 \mathrm{~g} \mathrm{l}^{-1}$ glucose, $10 \mathrm{~g} \mathrm{l}^{-1}$ yeast extract, $4.5 \mathrm{~g} \mathrm{l}^{-1}$ asparagine, $1 \mathrm{~g} \mathrm{l}^{-1}$ $\mathrm{MgSO}_{4}, 1.5 \mathrm{~g} \mathrm{l}^{-1} \mathrm{KH}_{2} \mathrm{PO}_{4}$ (pH 6.0, $300 \mathrm{ml}$, shake flasks, $24^{\circ} \mathrm{C}$ ). Cells were harvested by centrifugation $(5000 \times g)$ after $48 \mathrm{~h}$ and disintegrated in a bead mill. PDC was purified to homogeneity from the crude extract as described elsewhere (Neuser et al., 2000).

\section{Biotransformations with isolated PDC}

The reaction mixtures contained $2 \mathrm{~mm}$ ThDP, $20 \mathrm{~mm} \mathrm{MgSO}_{4}, 5 \mathrm{U}$ PDC (1 U catalyzes the decarboxylation of $1 \mu \mathrm{mol}$ pyruvate to acetaldehyde at $25^{\circ} \mathrm{C}$ in $1 \mathrm{~min}$ ) and equimolar amounts of sodium pyruvate and the respective aldehyde or acetaldehyde and the respective 2-oxo acid (15-200 mm) in $0.1 \mathrm{M}$ sodium citrate buffer ( $\mathrm{pH}$ 6.0, final volume $4 \mathrm{ml}$ ). After incubation at $24{ }^{\circ} \mathrm{C}$ for $48 \mathrm{~h}$, $200 \mu \mathrm{g} 2 E$-hexene-1-ol was added as internal standard, the mixtures were extracted with diethyl ether $(2 \times 2 \mathrm{ml})$ and the extracts dried over sodium sulfate.

\section{Identification of metabolites}

The organic extracts were analysed by capillary gas chromatography (HRGC) and gas chromatography-mass spectrometry (HRGC-MS). $\alpha$-Hydroxyketones were identified by comparing their Kovats indices and mass spectra with published data, if available, or with synthesized references (see below). HRGC was performed on a Fisons GC 8000 Series chromatograph equipped with an on-column inlet, a flame-ionization detector, a deactivated FS-CW precolumn $(3 \mathrm{~m} \times 0.32 \mathrm{~mm}$ i.d., CS, Germany), and a CW 20M fused silica column $(30 \mathrm{~m} \times 0.32 \mathrm{~mm}$ i.d., film thickness $0.25 \mu \mathrm{m}$, Macherey \& Nagel, Germany). Operating conditions were as follows: Carrier gas $\mathrm{H}_{2}$ at $3.2 \mathrm{ml}$ $\min ^{-1}$, injector $40^{\circ} \mathrm{C}$, detector $250^{\circ} \mathrm{C}$. The temperature was held at $40^{\circ} \mathrm{C}$ for $3 \mathrm{~min}$ and then increased to $230{ }^{\circ} \mathrm{C}$ at a rate of $4{ }^{\circ} \mathrm{C} \mathrm{min}{ }^{-1}$. Mass spectra were recorded by a Fisons MD 800 mass spectrometer, using electron ionization at $70 \mathrm{eV}$, $\mathrm{He}$ as carrier gas and the same HRGC conditions as above.

\section{Synthesis of reference acyloins}

Branched aliphatic acyloins (derived from the amino acids valine, leucine and isoleucine) were synthesized according to the method of Kawabata et al. (1978). For synthesis of the 2-hydroxy-3-oxoacyloins (2), (4) and (6), $0.1 \mathrm{~mol}$ (11.8 g) ethyl L-lactate was amidated by passing dry ammonia gas through the stirred liquid for $24 \mathrm{~h}$ at room temperature. After removal of the formed ethanol $0.05 \mathrm{~mol}$ (4.46 g) L-lactamide was added to a Grignard reagent prepared from $0.25 \mathrm{~mol}(6.08 \mathrm{~g}) \mathrm{Mg}$ turnings and $0.25 \mathrm{~mol}$ alkyl halide in $120 \mathrm{ml} \mathrm{di-}$ ethyl ether (30.8 $\mathrm{g}$ 2-bromopropane for synthesis of acyloin (2), 34.3 g 2-bromobutane for (4), and $34.3 \mathrm{~g}$ 1-bromo-2-methylpropane for (6), respectively). The acyloins were obtained after hydrolysis with $\mathrm{HCl}(6 \mathrm{~m})$ and extraction with ether.

For synthesis of the 3-hydroxy-2-oxo-acyloins (1), (3) and (5), $0.04 \mathrm{~mol}$ of the respective hydroxy acids 2-hydroxy isovaleric acid (5.15 g), 2-hydroxy3-methylvaleric acid (5.29 g) and 2-hydroxy isocaproic acid $(5.29 \mathrm{~g})$ were methylated with $\mathrm{MeOH}$ $(40 \mathrm{ml})$ in the presence of acetyl chloride $(3 \mathrm{ml})$. Since 2-hydroxy-3-methylvaleric acid was not commercially available, it was prepared by reduction of $0.05 \mathrm{~mol}(7.30 \mathrm{~g})$ 2-oxo-3-methylvaleric 
acid with $0.05 \mathrm{~mol}(2.0 \mathrm{~g}) \mathrm{NaBH}_{4}$. The respective hydroxy acid methyl esters $(0.03 \mathrm{~mol})$ were amidated as described above and $0.025 \mathrm{~mol}$ amide was then added to a Grignard reagent prepared from $0.125 \mathrm{~mol}(3.04 \mathrm{~g}) \mathrm{Mg}$ turnings and $0.125 \mathrm{~mol}$ $(17.7 \mathrm{~g})$ iodomethane in $60 \mathrm{ml}$ diethyl ether. All crude products were purified by column chromatography on silica gel.

Enantiomeric pure $R$-1-hydroxy-1-phenyl-2propanone (24) was a gift from Knoll AG (Germany) and was racemized by treatment with $0.1 \mathrm{M}$ sodium phosphate buffer (pH 7.7) at $90^{\circ} \mathrm{C}$. $R$ - and $S$-3-hydroxy-4-phenyl-2-butanone (21) were synthesized from $0.03 \mathrm{~mol}(5.0 \mathrm{~g}) R$ - and $S$-phenyl lactic acid, respectively, by methylation, amidation and Grignard addition with iodomethane, as explained above. S-3-hydroxy-1-phenyl-2-butanone (22) was synthesized by addition of $0.05 \mathrm{~mol}$ $(4.46 \mathrm{~g})$ L-lactamide to a Grignard reagent prepared from $0.25 \mathrm{~mol}(6.08 \mathrm{~g}) \mathrm{Mg}$ and $0.25 \mathrm{~mol}$ $(42.8 \mathrm{~g}$ ) benzyl bromide in $120 \mathrm{ml}$ ether. $R, S$-3-hydroxy-1-phenyl-2-butanone was synthesized according to the method of Gill et al. (1986). $0.1 \mathrm{~mol}$ $(10.8 \mathrm{~g})$ trimethylsilylchloride was added dropwise to a mixture of $0.1 \mathrm{~mol} \mathrm{D,L}$-lactonitrile and $0.1 \mathrm{~mol}$ $(7.9 \mathrm{~g})$ pyridine in $50 \mathrm{ml}$ dry ether and stirred over night. The formed precipitate was seperated by filtration and the ether removed under reduced pressure. The silylated nitrile was then added to a Grignard reagent prepared from $0.1 \mathrm{~mol}(2.45 \mathrm{~g})$ $\mathrm{Mg}$ and $0.1 \mathrm{~mol}(12.7 \mathrm{~g})$ benzylchloride in $80 \mathrm{ml}$ ether. Crude products were purified by preparative HPLC on a Lichrosorb Diol column $(7 \mu \mathrm{m}$, $250 \times 25 \mathrm{~mm}$, Merck, Germany). HPLC was performed with a Jasco PU-980 intelligent HPLC gradient pump, a Jasco gradient former and a LC-UVDetector (Pye Unicam, $\lambda=260 \mathrm{~nm}$ ). Chromatographic conditions: Sample volume $2 \mathrm{ml}$, flow rate $10 \mathrm{ml} \mathrm{min}{ }^{-1}$, linear elution gradient from hexane $(100 \%)$ to hexane/isopropanol $(95 / 5 \mathrm{v} / \mathrm{v})$ in $80 \mathrm{~min}$.

$R, S$-3-Hydroxy-2-octanone (23) was obtained by bromination of $0.04 \mathrm{~mol}(5.2 \mathrm{~g})$ 2-octanone with $0.16 \mathrm{~mol}(22.6 \mathrm{~g})$ 2-bromo-2-methylpropane in $0.08 \mathrm{~mol}(6.2 \mathrm{~g})$ DMSO (12 h reflux) and following hydrolysis of the resulting 3-bromo-2-octanone with $50 \mathrm{ml}$ saturated $\mathrm{NaHCO}_{3}$-solution $(8 \mathrm{~h}$ at $90{ }^{\circ} \mathrm{C}$ ) (Spiteller et al., 1980; Armani et al., 1984).

\section{Chiral analysis}

The enantiomeric distribution of the enzymatically produced $\alpha$-hydroxyketones was determined by HRGC after derivatization to diastereomeric MTPA-esters. $10-100 \mu \mathrm{g}$ acyloin in $50 \mu \mathrm{l}$ dry diethyl ether was mixed with $4 \mu \mathrm{l}$ pyridine and $2 \mu \mathrm{l}$ $S$-2-methoxy-2-trifluoromethyl-2-phenylacetyl chloride ( $S$-MTPA-Cl). After $16 \mathrm{~h}$ at room temperature the mixture was diluted with ether and analysed by HRGC-MS (as described above) on a BC SE 54 column $(30 \mathrm{~m} \times 0.32 \mathrm{~mm}$ i.d., film thickness $0.4 \mu \mathrm{m}$, Leupold, Germany) under isothermal conditions $\left(180{ }^{\circ} \mathrm{C}\right.$ for (21) and $(\mathbf{2 4}), 165{ }^{\circ} \mathrm{C}$ for (22) and $130^{\circ} \mathrm{C}$ for (23), respectively). Absolute configurations were determined by comparison with racemic and enantiomeric pure standards, which were analysed in the same way. The absolute configuration of enzymatically produced 3-hydroxy-2-octanone was identified by measuring the optical rotation (Perkin Elmer polarimeter 341, $\lambda=589 \mathrm{~nm}) \cdot \alpha_{\mathrm{J}}^{25}(\mathrm{~S}-(\mathbf{2 3}))=+92^{\circ}$ (Bel-Rhlid et al. 1989).

Enzymatically synthesized acyloins were isolated by column chromatography or preparative HPLC as described above for the reference substances.

\section{Results}

\section{Yeast biotransformations}

Five of several amino acids tested were converted by fermenting yeast cells of Zygosaccharomyces bisporus to the corresponding $\alpha$-hydroxyketones (phenylalanine, tyrosine, valine, leucine, methionine), but only the two aromatic precursors gave larger product yields (Table I). No acyloin formation was observed with isoleucine, histidine, threonine and glutamic acid. Replacement of the convertable amino acids by their corresponding 2-oxo acids (if available) led to improved product yields and, moreover, to the first detection of the acyloins derived from isoleucine (Table I). The main transformation products proved to be the alcohols formed by transamination of the amino acids, subsequent decarboxylation and reduction by ADH (Fig. 1). There are two possible pathways of acyloin formation, leading to the shown isomeric structures. If amino acids or 2-oxo acids were added to the yeast cultures, the 2-hydroxy-3oxo-acyloins represented the predominant isomer 
Table I. Formation of acyloins (total of both isomers) by fermenting cells of Zygosaccharomyces bisporus from different precursors (concentration $10 \mathrm{~mm}$ ).

\begin{tabular}{lcc}
\hline Precursor & $\begin{array}{l}\text { Acyloin from } \\
\text { amino acid } \\
{\left[\mathrm{mg} \mathrm{l}^{-1}\right]}\end{array}$ & $\begin{array}{l}\text { Acyloin from } \\
\text { 2-oxo acid } \\
{\left[\mathrm{mg} \mathrm{l}^{-1}\right]}\end{array}$ \\
\hline $\begin{array}{l}\text { Phenylalanine } \\
\text { Phenylpyruvic acid } \\
\begin{array}{l}\text { Tyrosine } \\
\text { 4-Hydroxyphenylpyruvic acid } \\
\text { Valine }\end{array}\end{array}$ & 15.9 & 17.5 \\
$\begin{array}{l}\text { 3-Methyl-2-oxobutyric acid } \\
\text { Leucine }\end{array}$ & 0.19 & 25.9 \\
$\begin{array}{l}\text { 3-Methyl-2-oxovaleric acid } \\
\text { Isoleucine } \\
\text { 4-Methyl-2-oxovaleric acid }\end{array}$ & 0.09 & 0.49 \\
\begin{tabular}{l} 
Methionine \\
\hline
\end{tabular} & 0 & 0.51 \\
\hline
\end{tabular}

formed (>90\%). Keto-enol tautomerization was observed with all secondary $\alpha$-hydroxyketones and, thus, both possible isomers always occurred, especially in the presence of acids or higher temperatures.

\section{Biotransformations using isolated PDC}

In order to confirm the two proposed pathways shown in Fig. 1 and to gain further insight in the role of pyruvate decarboxylase in the biosynthesis of the $\alpha$-hydroxyketones obtained, incubation experiments with isolated PDC from Zygosaccharomyces bisporus were carried out. First, aldehydes and 2-oxo acids corresponding to the successfully converted amino acids (if available) were incubated in the presence of pyruvate and acetaldehyde, respectively. 12 further aldehydes and two 2oxo acids containing different structure elements (branched, unsaturated) were then checked for their precursor properties. As summarized in Table II, all of the aldehydes and most of the 2-oxo acids were converted to the expected acyloin isomers; merely 2-oxo glutaric acid and 4-hydroxyphenylpyruvate failed to yield the expected products. The condensation of aldehydes and pyruvate resulted in the formation of 3-hydroxy-2oxo-acyloins as the main transformation products, while 2-oxo acids and acetaldehyde predominantly gave 2-hydroxy-3-oxo-acyloins. Acetoin resulting from condensation of pyruvate and acetaldehyde, or two molecules of acetaldehyde, was detected as side product only. The application of aliphatic aldehydes of different homologous series revealed several factors influencing their conversion to $\alpha$-hydroxyketones by PDC. The improved substrate suitability of long-chain aldehydes shows the importance of hydrophobic molecule properties, whereas the significantly worse transformation of branched aldehydes may be attributed to the steric hindrance of such structures. $\alpha, \beta$-unsaturated aldehydes showed lower conversion rates than their saturated analoga, which might be due to steric reasons (more rigid structure), changes in the reactivity of the carbonyl group and/or slightly different polarities. Remarkable differences in acyloin formation were shown upon incubation of the

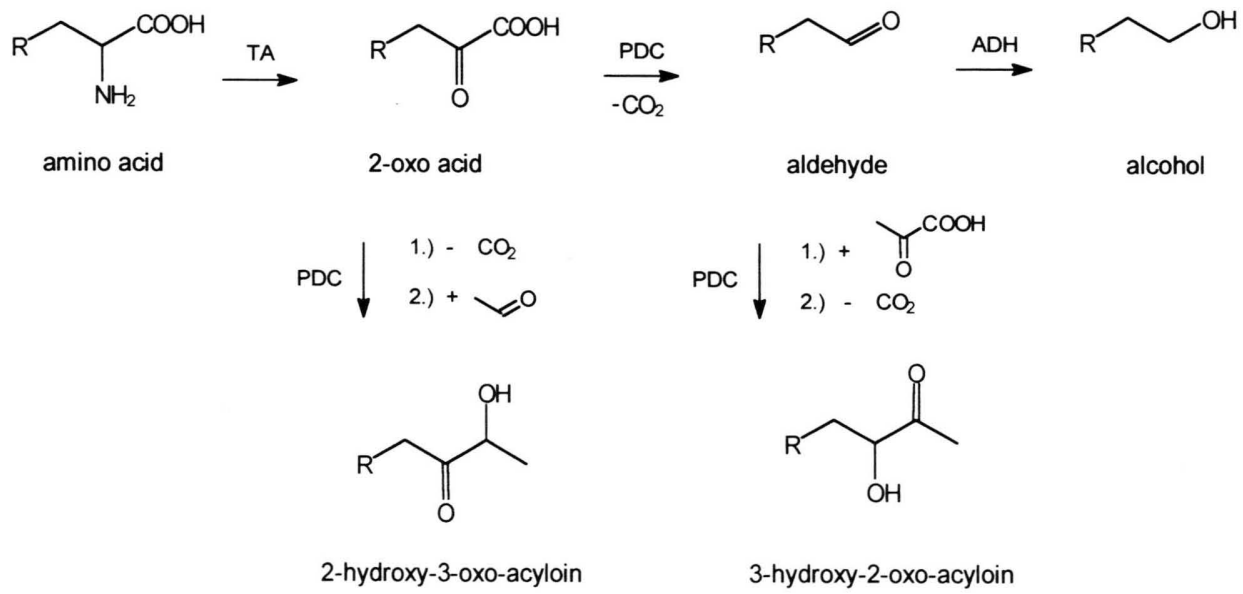

Fig. 1. Proposed formation of $\alpha$-hydroxyketones from amino acids by yeasts $(\mathrm{TA}=$ transaminase, $\mathrm{PDC}=$ pyruvate decarboxylase, $\mathrm{ADH}=$ alcohol dehydrogenase). 
Table II. Formation of acyloins (total of both isomers) from different precursors ( $\mathrm{c}_{0}$ $118 \mathrm{~mm}$ ) by isolated pyruvate decarboxylase.

\begin{tabular}{lcc}
\hline Precursor & $\begin{array}{c}\text { Acyloin from aldehyde } \\
\text { and pyruvate }\left[\mathrm{mg} \mathrm{l}^{-1}\right]\end{array}$ & $\begin{array}{c}\text { Acyloin from 2-oxo acid } \\
\text { and acetaldehyde }\left[\mathrm{mg} \mathrm{l}^{-1}\right]\end{array}$ \\
\hline Propanal/ & 197 & 149 \\
2-Oxobutanoic acid & 300 & \\
Butanal & 636 & 14 \\
Pentanal & 1992 & 43 \\
Hexanal & 2489 & 40 \\
Heptanal & 62 & \\
\hline 2-Methylpropanal/ & & \\
3-Methyl-2-oxobutanoic acid & 42 & \\
3-Methylbutanal/ & & \\
4-Methyl-2-oxopentanoic acid & 83 & \\
2-Methylbutanal/ & 92 & \\
3-Methyl-2-oxopentanoic acid & 136 & \\
2-Methylpentanal & 319 & \\
\hline 2E-Butenal & 517 & \\
2E-Pentenal & 65 & \\
2E-Hexenal & 93 & \\
\hline 2-Methyl-2E-butenal & 50 & \\
3-Methyl-2E-butenal & 2382 & \\
\hline 3-(Methylthio)propanal & & \\
\hline Benzaldehyde/ & & \\
Benzoylformic acid & & \\
Phenylacetaldehyde/ & & \\
Phenylpyruvic acid & & \\
\hline & & \\
\hline
\end{tabular}

aromatic compounds benzaldehyde and phenylacetaldehyde, the latter one resulting in product amounts tenfold lower than observed with benzaldehyde.

Compounds (1) to (20) (with the exception of (3), Moio et al., 1994) have not been reported as natural products before and no mass spectrometric data were thus available for their identification. Acyloins (1) to (6) were therefore synthesized as references. All of them showed mass spectra and retention indices identical to those obtained by enzymatic conversion. Highly characteristic fragmentation patterns of these compounds also allowed the identification of further examined $\alpha$-hydroxyketones by their mass spectra. In each case, two primary fragments, $m / z=45$ and $\mathrm{M}^{+}-45$ (2-hydroxy-3-oxo-acyloins), or $m / z=43$ and $\mathbf{M}^{+} \cdot-43$ (3-hydroxy-2-oxo acyloins), resulted from $\alpha$-cleavage between $\mathrm{C} 2$ and $\mathrm{C} 3$. Subsequently, $\mathrm{CO}$ is eliminated from the $\left(\mathrm{M}^{+}-45\right)$-fragment to give
$\left(\mathrm{M}^{+} \cdot-45-28\right)$, whereas $\mathrm{H}_{2} \mathrm{O}$ is split off from $\left(\mathrm{M}^{+} \cdot-43\right)$ to give $\left(\mathrm{M}^{+\cdot}-43-18\right)$. Due to this recurring scheme and the fact that the respective acyloins were by far the main products of all studied biotransformations, further identifications were based on the mass spectrometric data without synthesis of reference substances (Table III). Surprisingly and in contrast to all other examples, the two isomers of acyloins branched at C4 (5) and (6), as well as (7) and (8), respectively, showed almost identical mass spectra, although being clearly separated by GC-MS. This may be explained by heatcatalysed elimination of water at $\mathrm{C} 3 / \mathrm{C} 4$ leading to a comparably stable tertiary carbocation, which is only possible from the 3-hydroxy-2-oxo-acyloin, thus favouring the keto-enol tautomerization in one direction. It has to be considered, however, that the hydroxy pentanones (1) and (2), branched at $\mathrm{C} 4$, too, did not show this peculiar fragmentation. 
Table III. Mass spectrometric data of acyloins produced by pyruvate decarboxylase.

\begin{tabular}{|c|c|c|c|}
\hline Residue & $\operatorname{Pr}$ & ucts & $m / z(\%$ relative abundance $)$ \\
\hline & (1) & (2) & $\begin{array}{l}116\left(\mathrm{M}^{+}, 0.4\right), 73(96), 55(100), 45(27), 43(94) \\
116(1), 71(28), 45(100), 43(84)\end{array}$ \\
\hline & (3) & (4) & $\begin{array}{l}130(0.3), 87(25), 69(63), 45(42), 43(100) \\
130(0.7), 85(65), 57(100), 45(83), 43(31)\end{array}$ \\
\hline & (5) & (6) & $\begin{array}{l}130(0.3), 87(33), 74(26), 69(27), 57(22), 45(55), 43(100) \\
130(0.4), 87(32), 74(28), 69(26), 57(22), 45(52), 43(100)\end{array}$ \\
\hline & (7) & (8) & $\begin{array}{l}144(0.2), 101(32), 83(50), 74(35), 55(61), 45(55), 43(100) \\
144(0.2), 101(61), 83(52), 74(35), 55(59), 45(57), 43(100)\end{array}$ \\
\hline & (9) & $(\mathbf{1 0})$ & $\begin{array}{l}148(18), 105(16), 75(75), 61(100), 45(36), 43(62) \\
148(23), 104(15), 75(52), 61(100), 45(84), 43(38)\end{array}$ \\
\hline & (11) & (12) & $\begin{array}{l}114(2), 71(100), 53(37), 43(83), 41(59) \\
114(1), 69(100), 45(45), 43(21), 41(49)\end{array}$ \\
\hline & (13) & (14) & $\begin{array}{l}128(1), 85(93), 67(33), 57(56), 43(100), 41(66) \\
128(1), 83(100), 55(54), 45(100), 43(66)\end{array}$ \\
\hline & (15) & (16) & $\begin{array}{l}142(0.2), 99(28), 57(100), 43(35) \\
142(0.2), 97(64), 69(10), 55(100), 45(34)\end{array}$ \\
\hline & (17) & (18) & $\begin{array}{l}128(3), 85(100), 55(30), 43(71), 41(48) \\
\mathbf{1 2 8}(2), 83(67), 55(100), 45(48), 43(28)\end{array}$ \\
\hline & (19) & $(20)$ & $\begin{array}{l}128(1), 85(100), 55(32), 43(37), 41(51) \\
128(1), 83(100), 55(50), 45(14), 43(13)\end{array}$ \\
\hline & (21) & (22) & $\begin{array}{l}164(0.3), 121(49), 103(59), 91(100), 65(32), 43(46) \\
164(1), 120(21), 91(100), 65(33), 45(53)\end{array}$ \\
\hline
\end{tabular}

\section{Substrate suitability}

With regard to product yields, aldehydes proved to be the more effective precursors compared to the corresponding 2-oxo acids (Table II). Within the homologous series of saturated linear aldehydes, acyloin formation increased with growing carbon chain length. The same tendency was observed with unsaturated linear aldehydes, but yielding considerably less product amounts than the saturated substrates of equal chain length. Branched aldehydes were poor precursors compared to linear ones. Benzaldehyde was converted at much higher rates than the second aromatic substrate, phenylacetaldehyde. The frequently discussed opinion that pyruvate decarboxylase would show a high substrate specifity for aromatic aldehydes in acyloin formation (Fuganti and Grasselli, 1985; Long et al., 1989; Bornemann et al., 1996) did not apply for the enzyme of $Z$. bisporus.

\section{Stereospecifity of acyloin formation}

The enantiomeric distribution of enzymatically produced acyloins was determined for 3-hydroxy4-phenyl-2-butanone (21) and 3-hydroxy-1-phenyl-2-butanone (22) as aromatic representatives, 
for 3-hydroxy-2-octanone as an aliphatic compound (23), and for 1-hydroxy-1-phenyl-2-propanone (PAC) (24) as the best studied product in order to compare the obtained results with published data. Benzaldehyde and benzoylformic acid were both converted to $R$-(24) in optical purities $\geq 98 \%$ by isolated PDC as well as by fermenting yeast cells of Zygosaccharomyces bisporus (Table IV). The isomeric 2-hydroxy-1-phenyl-1-propanone (25) as the expected main conversion pro-

Table IV. Enantiomeric distribution of $\alpha$-hydroxyketones produced by purified pyruvate decarboxylase and fermenting yeast cells of $Z$. bisporus.

\begin{tabular}{lcrcc}
\hline Precursor & \multicolumn{2}{c}{$\begin{array}{c}\text { Main isomer and optical purity (\% ee) } \\
\text { PDC }\end{array}$} & \multicolumn{2}{c}{ Yeast } \\
\hline Benzaldehyde & $R-(\mathbf{2 4})$ & $\geq 98 \%$ & $R-(\mathbf{2 4})$ & $\geq 98 \%$ \\
Benzoylformic acid & $R-(\mathbf{2 4})$ & $\geq 98 \%$ & & - \\
Phenylacetaldehyde & $R-(\mathbf{2 1})$ & $58 \%$ & & - \\
Phenylpyruvate & $S-(\mathbf{2 2})$ & $30 \%$ & $S-(\mathbf{2 2})$ & $84 \%$ \\
Hexanal & $R-(\mathbf{2 3})$ & $69 \%$ & & - \\
\hline
\end{tabular}

duct of benzoylformic acid was detectable only in small amounts $(<3 \%)$.

Conversion of phenylacetaldehyde and hexanal also yielded the respective $R$ - $\alpha$-hydroxy-ketones. The products $R-(\mathbf{2 1})$ and $R-(\mathbf{2 3})$ were, however, of considerably lower optical purity than compound $R$-(24) (Table IV). In contrast, the biotransformation of phenylpyruvate by PDC or whole yeast cells led to acyloin $S$-(22), thus being of opposite configuration than all other examples studied here or reported in literature.

\section{Discussion}

The mechanism of decarboxylation and carboligation by pyruvate decarboxylase has been studied intensively serving as a model reaction for thiamine-dependent enzymes (recent reviews: Pohl, 1997; Schellenberger, 1998). The different steps relevant for ThDP-catalysed decarboxylation and the formation of $\alpha$-hydroxyketones are summarized in Fig. 2. Carbanion $\mathbf{1}$ as reactive intermedi-

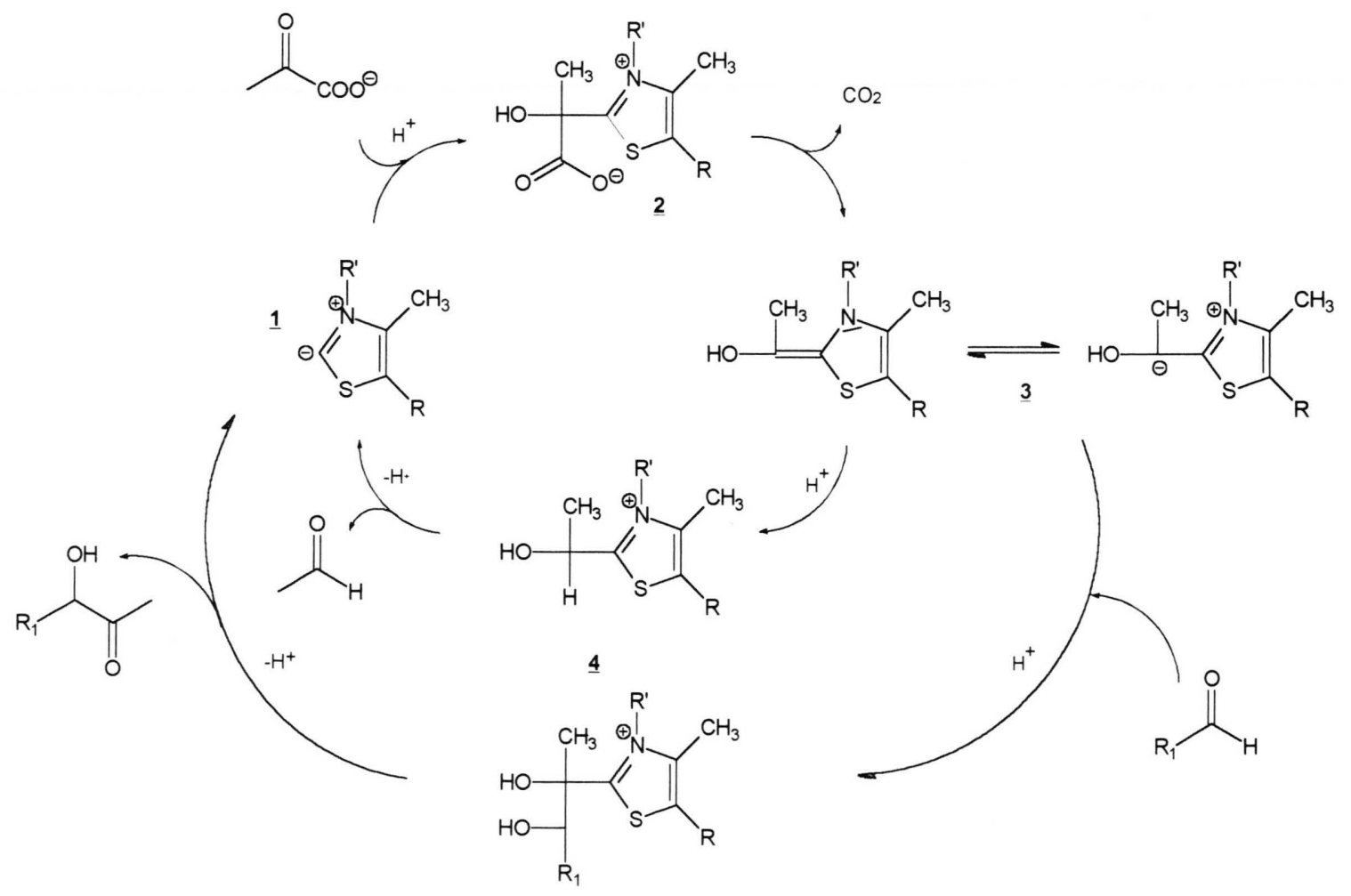

Fig. 2. Reaction path of enzymatic pyruvate decarboxylation and formation of $\alpha$-hydroxy-ketones. 
ate performs a nucleophilic attack on the $\alpha$-carbonyl group of the keto acid. Decarboxylation leads to a carbanion-enamine intermediate $\mathbf{3}$, also known as "active aldehyde", probably present in the mechanism of all ThDP-dependent enzymes (Iding et al., 1998). A further protonation step gives compound $\mathbf{4}$, which is regenerated to ThDP after release of the produced aldehyde. In the presence of higher concentrations of a second aldehyde, however, carbanion 3 can perform a nucleophilic attack on the carbon atom of the carbonyl group to form an $\alpha$-hydroxyketone. Since the protonation step to $\mathbf{4}$ is reversible (Chen and Jordan, 1984), intermediate $\mathbf{3}$ may also be obtained upon addition of an aldehyde to ThDP and subsequent deprotonation, allowing the formation of $\alpha$-hydroxyketones from two aldehydes or two molecules of a single aldehyde as precursors, irrespective of the presence of 2-oxo acids. This was revealed here by the formation of acetoin from acetaldehyde in the absence of pyruvate, although as side product only. Moreover, benzoylformic acid was not converted to the expected 2-hydroxy1-phenyl-1-propanone (25) but to the isomeric acyloin $R$-(24) as observed with benzaldehyde. This unusual result can be explained by the assumption that after decarboxylation of benzoylformic acid benzaldehyde is first cleaved from the enzyme-product complex before reacting with a carbanion intermediate derived from ThDP and the co-substrate acetaldehyde.

Armani E., Dossena A., Marchelli R. and Casnati G. (1984), Reaction of aldehydes and ketones with $t$-butyl bromide-dimethyl sulphoxide. Tetrahedron $\mathbf{4 0}$, 2035-2039.

Bel-Rhlid R., Fauve A. and Veschambre H. (1989), Synthesis of the pheromone components of the grape borer Xylotrechus pyrrhoderus by microbiological reduction of an $\alpha$-diketone. J. Org. Chem. 54, $3221-3223$.

Bornemann S., Crout D. H. G., Dalton H., Kren V., Lobell M., Dean G., Thomson N. and Turner M. M. (1996), Stereospecific formation of $R$-aromatic acyloins by Zymomonas mobilis pyruvate decarboxylase. J. Chem. Soc., Perkin Trans. 1, 425-430.

Bringer-Meyer S., Schimz K.-L. and Sahm H. (1986), Pyruvate decarboxylase from Zymomonas mobilis. Isolation an partial characterization. Arch. Microbiol. 146, $105-110$.
Stereo-control of the described carboligase reaction led to the production of $R$-acyloins from aldehyde precursors. The high optical purity of $R$ 1-hydroxy-1-phenyl-2-propanone (24) ( $\geq 98 \%$ ee) derived from benzaldehyde is consistent with published data (Kren et al., 1993; Lobell and Crout, 1996; Pohl, 1997). Benzoylformic acid (+ acetaldehyde) was converted to acyloin $R$-(24) in the same enantiomeric excess observed with benzaldehyde, supporting the above discussed assumption that the same reaction path as with benzaldehyde (+ pyruvate) was followed. Hexanal and phenylacetaldehyde were transformed by PDC to the acyloins $R$-3-hydroxy-2-octanone (23) and $R$-3-hydroxy-4-phenyl-2-butanone (21), respectively. The considerably lower optical purities of $69 \%$ and $58 \%$ ee may be attributed to a decreased stereo-selectivity of PDC towards aliphatic substrates and aromatic substrates with aliphatic side chains due to a less strictly orientated substrate binding.

$S$-3-hydroxy-1-phenyl-2-butanone (22) prepared from phenylpyruvate using cultures of $Z$. bisporus or isolated PDC was the only acyloin detected being predominantly of $S$-configuration. The low optical purity of enzymatically formed (22) does probably not represent the actual PDC stereo-selectivity. Racemisation via keto-enol tautomerization, which was particularly observed with poor substrates, such as phenylpyruvate, should rather be considered as a reason for this result.

Bringer-Meyer S. and Sahm H. (1988), Acetoin and phenylacetylcarbinol formation by the pyruvate decarboxylases of Zymomonas mobilis and Saccharomyces carlsbergensis. Biocatalysis 1, 321-331.

Cardillo R., Servi S. and Tinti C. (1991), Biotransformation of unsaturated aldehydes by microorganisms with pyruvate decarboxylase activity. Appl. Microbiol. Biotechnol. 36, 300-303.

Chen G. C. and Jordan F. (1984), Brewer's yeast pyruvate decarboxylase produces acetoin from acetaldehyde: A novel tool to study the mechanism of steps subsequent to carbon dioxide loss. Biochemistry 23, 3576-3582.

Crout D. H. G., Dalton H., Hutchinson D. W. and Miyagoshi M. (1991), Studies on pyruvate decarboxylase: Acyloin formation from aliphatic, aromatic and heterocyclic aldehydes. J. Chem. Soc. Perkin Trans. 1, $1329-1334$. 
Dirscherl W. (1931), Mechanismus und Kinetik der Acyloinbildung bei der Gärung. 3. Mitteilung über Acyloine. Hoppe-Seylers Z. physiol. Chem. 201, 47-77.

Fuganti C. and Grasselli P. (1985), Stereochemistry and synthetic applications of products of formation of $\alpha, \beta$ unsaturated aromatic aldehydes by baker's yeast. In: Enzymes in Organic Synthesis (Pitman London, Ciba Foundation symposium 111), pp 112-127.

Gill M., Kiefel M. J. and Lally D. A. (1986), Addition of organomagnesium reagents to cyanohydrin-O-silyl ethers: An efficient and flexible synthesis of unsymmetrically substituted acyloins. Tetrahedron Lett. 27, $1933-1934$.

Gounaris A. D., Turkenkopf I., Civerchia L. L. and Grennlie J. (1975) Pyruvate decarboxylase III: Specificity restrictions for thiamine pyrophosphate in the protein association step, subunit structure. Biochim. Biophys. Acta 405, 492-499.

Iding H., Siegert P., Mesch K. and Pohl M. (1998), Application of $\alpha$-keto acid decarboxylases in biotransformations. Biochim. Biophys. Acta 1385, 307-322.

Kawabata J., Tahara S. and Mizutani J. (1978), 2S,3Rtrans-4-trans-6-octadiene-2,3-diol: Structure and absolute configuration of a novel metabolite of sorbic acid. Agric. Biol. Chem. 42, 89-94.

Kern D., Kern G., Neef H., Tittmann K., Killenberg-Jabs M., Wikner C., Schneider G. and Hübner G. (1997), How thiamine diphosphate is activated in enzymes. Science 275, 67-70.

Kren V., Crout D. H. G., Dalton H., Hutchinson D. W., König W., Turner M. M., Dean G. and Thomson N. (1993), Pyruvate decarboxylase: a new enzyme for the production of acyloins by biotransformation. J. Chem. Soc., Chem. Comm., 341-343.

Lobell M. and Crout D. H. G. (1996), Pyruvate decarboxylase: A molecular modelling study of pyruvate decarboxylation and acyloin formation. J. Am. Chem. Soc. 118, $1867-1873$.

Long A., James P. and Ward O. P. (1989), Aromatic aldehydes as substrates for yeast and yeast alcohol dehydrogenase. Biotechnol. Bioeng. 33, 657-660.
Moio L., Semon E. and Le Quere J. L. (1994), 3-Hydroxy-5-methyl-2-hexanone, a new compound characterized by a melted cheese flavour in dairy products Ital. J. Food Sci. 6, 441-447.

Mücke U., König S. and Hübner G. (1995), Purification and characterisation of pyruvate decarboxylase from pea seeds (Pisum sativum cv. Miko). Biol. Chem. Hoppe-Seyler 376, 111-117.

Neuberg C. and Karczag L. (1911), Über zuckerfreie Hefegärungen. IV. Carboxylase, ein neues Enzym der Hefe. Biochem. Z. 36, 68-81.

Neuberg C. and Hirsch J. (1921), An enzyme which brings about union into carbon chains (carboligase). Biochem. Z. 115, 282-310.

Neuser F., Richter U. and Berger R. G. (1999), Aromarelevante $\alpha$-Hydroxyketone aus lebensmittelnahen Wildhefen. Lebensmittelchemie 53, 4.

Neuser F.; Zorn H.; Richter U.; Berger R. G. (2000) Purification, characterisation and cDNA sequencing of pyruvate decarboxylase from Zygosaccharomyces bisporus. Biol. Chem., in press

Pohl M. (1997), Protein design on pyruvate decarboxylase (PDC) by site directed mutagenesis. Adv. Biochem. Eng. 58, 15-43.

Rivoal J., Ricard B. and Pradet A. (1990), Purification and partial characterization of pyruvate decarboxylase from Oryza sativa L. Eur. J. Biochem. 194, 791797.

Schellenberger A. (1998), Sixty years of thiamine diphosphate biochemistry. Biochim. Biophys. Acta 1385, $177-186$.

Schmauder H.-P. and Gröger D. (1968), Studien zur Acyloinbildung durch Saccharomyces cerevisiae. Pharmazie 23, 320-331.

Spiteller M., Spiteller G. and Hoyer G.-A. (1980), Urofuransäuren - eine bisher unbekannte Klasse von Stoffwechselprodukten. Chem. Ber. 113, 699-709.

Zehender H., Trescher D. and Ullrich J. (1987), Improved purification of pyruvate decarboxylase from wheat germ. Its partial characterisation and comparison with the yeast enzyme Eur. J. Biochem. 167, $149-154$. 